\title{
Article \\ Coral Recovery in the Central Mexican Pacific 20 Years after the 1997-1998 El Niño Event
}

\author{
Violeta Martínez-Castillo ${ }^{1}$ (D) Alma Paola Rodríguez-Troncoso ${ }^{1, *(D)}$, Anderson B. Mayfield ${ }^{2,3}$ (D), \\ Fabián Alejandro Rodríguez-Zaragoza ${ }^{4}$ (D) and Amílcar Leví Cupul-Magaña ${ }^{1}$ (D)
}

1 Laboratorio de Ecología Marina, Centro Universitario de la Costa, Universidad de Guadalajara, Puerto Vallarta 48280, Jalisco, Mexico; viomarcast@gmail.com (V.M.-C.); amilcar.cupul@gmail.com (A.L.C.-M.)

2 National Museum of Marine Biology and Aquarium, Township, Pingtung County 944, Taiwan; anderson.mayfield@noaa.gov

3 Atlantic Oceanographic and Meteorological Laboratory, National Oceanic and Atmospheric Administration, Biscayne, FL 33149, USA

4 Laboratorio de Ecología Molecular, Microbiología y Taxonomía, Centro Universitario de Ciencias Biológicas y Agropecuarias, Universidad de Guadalajara, Zapopan 44600, Jalisco, Mexico; fabian.rzaragoza@academicos.udg.mx

* Correspondence: pao.rodriguezt@gmail.com or alma.rtroncoso@academicos.udg.mx; Tel.: +52-322-134-8009

check for

updates

Citation: Martínez-Castillo, V.; Rodríguez-Troncoso, A.P.; Mayfield, A.B.; Rodríguez-Zaragoza, F.A.; Cupul-Magaña, A.L. Coral Recovery in the Central Mexican Pacific 20 Years after the 1997-1998 El Niño Event. Oceans 2022, 3, 48-59. https://doi.org/10.3390/ oceans3010005

Academic Editor: Michael W. Lomas

Received: 8 December 2021

Accepted: 11 February 2022

Published: 17 February 2022

Publisher's Note: MDPI stays neutral with regard to jurisdictional claims in published maps and institutional affiliations.

Copyright: (c) 2022 by the authors. Licensee MDPI, Basel, Switzerland. This article is an open access article distributed under the terms and conditions of the Creative Commons Attribution (CC BY) license (https:// creativecommons.org/licenses/by/ $4.0 /)$.

\begin{abstract}
El Niño-Southern Oscillation (ENSO) events are increasing globally in both frequency and strength, and they can elicit coral bleaching events. The 1997-1998 ENSO caused mass coral mortality with a $96 \%$ decline in live coral cover along the Central Mexican Pacific. However, in recent years, these sites have shown signs of recovery. We used data collected in 1997 and 2015-2017 to evaluate the coral recovery in this region and coral cover levels have now reached $50 \%$ of their pre1997-1998 El Niño values. Furthermore, a strong 2015-2016 ENSO event did not significantly affect the live coral cover, potentially demonstrating that the local corals have acclimatized or even adapted to higher temperatures. Even though branching species remain the most abundant morphotype, a PERMANOVA revealed significant changes in the coral assemblage. Collectively, this dataset is testament to the fact that corals within this region are capable of resisting or at least partially recovering from thermal anomalies caused by ENSO events.
\end{abstract}

Keywords: coral bleaching; ecological resilience; El Niño-Southern Oscillation; environmental recovery; hermatypic corals; ocean warming

\section{Introduction}

Coral reefs, considered to be amongst the most ecologically and economically valuable marine ecosystems [1,2], are declining worldwide due to increasing seawater temperatures brought upon by climate change [3-5]; half of the coral reefs of the world have been already lost [6]. When abnormally high temperatures persist for extended periods (days-weeks), coral bleaching can occur. Given the reef coral dependency on their photosynthetically active endosymbionts for food, bleaching can result in a partial or complete coral colony mortality followed by the degradation of the reef [7]. Increases of only $+1{ }^{\circ} \mathrm{C}$ above the annual summer mean may trigger bleaching [8]. As such, El Niño-Southern Oscillation (ENSO) events, which can feature temperatures of $+2-3{ }^{\circ} \mathrm{C}$ above the summer maxima for extended periods (usually six weeks or more), can cause bleaching events, mass coral mortality (and, consequently, reductions in the coral cover), and reef degradation [9]. Since the 1980s, four strong ENSO events have caused a massive global loss of coral, and three of them (1982-1983, 1997-1998, and 2015-2016) have been particularly harmful to coral ecosystems in the Eastern Tropical Pacific (ETP) [4,10-12].

ENSO events and, more generally, elevated temperatures, affect corals differently in different regions; certain taxa are notably more tolerant than others [13]. Such differential 
responses have been attributed to life-history traits, a local acclimatization capacity [14,15], and other factors; this heterogeneity means that many reefs respond to temperature anomalies in ways that are hard to predict [16]. Understanding how coral reefs are recovering from bleaching events is important for assessing their ability to survive future changes in their environments, especially in regions severely affected by ENSO events such as the ETP. Although there are available data on coral recovery after mass bleaching events in the ETP $[10,11,17]$, this region still remains vastly understudied compared with other coral reef systems; only a few sites have been monitored over decadal timescales [17]. In the Central Mexican Pacific (CMP), the intense 1997-1998 bleaching event caused a >95\% decrease in the live coral cover [18]. Despite this loss, recent observations suggest that CMP coral ecosystems are not only recovering but also appear to be more resistant to global stressors such as ENSO events $[14,15,17,19]$, pers. observ. As this apparent recovery has not been quantified, we compared the coral composition before the 1997-1998 ENSO event $[18,20]$ with survey data from 2015-2017 and hypothesized that the reef assemblage may have significantly changed over time in response to repeated ENSO and other stress events.

\section{Materials and Methods}

The coral ecosystem surveyed is located in the northern limits of the ETP; it is a CMP site known as "Punta de Mita" $\left(20.7699^{\circ} \mathrm{N}, 105.5412^{\circ} \mathrm{W}\right)$. The CMP is considered to be an oceanographic transition zone as the cold California Current and the southerly flowing warm waters from the Gulf of California converge with the warm coastal Mexican current running north at this location [21] (Figure 1a). This creates a complex dynamic in the region, where water moves north by northwest during summer and fall; during the rest of the year, it flows south by southwest with seasonal upwelling events during spring [22]. A geostrophic current inside the bay generally flows north [23] (Figure 1b) and the sea surface temperature ranges from 18 to $32^{\circ} \mathrm{C}$ with an annual mean of $\sim 27^{\circ} \mathrm{C}$ [24]. The temperature peaks in summer, albeit with daily drops associated with internal waves [22,25].

The in situ coral cover was determined by scuba diving from eight survey times at depths of $\sim 3 \mathrm{~m}$ before the 1997-1998 ENSO event and in 2015, 2016, and 2017. The surveys for each year were carried out during both winter and summer to obtain the mean $\%$ live coral cover (LCC) per year using two different approaches. In 1997, before the study site was affected by the 1998 ENSO event, the cover was estimated using 3 permanent line transects of $10 \mathrm{~m}$ laid parallel to the coast. The coral cover was assessed within 10 quadrats of $1 \mathrm{~m}^{2}$ positioned along each transect. For the 2015-2017 surveys, 3 transects of $25 \mathrm{~m}$ were placed at the same site as in 1997 in both seasons; however, to improve the comparability with studies undertaken elsewhere in the Mexican Pacific, the coral cover was assessed within 6 quadrats of $1 \mathrm{~m}^{2}$ randomly placed along each transect- the new official methodology specifically standardized for this region. The second reason for this shift in methodology was because the prevailing area where the corals were found shifted over the 20-year period (discussed in the Results section), increasing its area.

In each of the 24 transects, the coral cover was documented overall and at the species level, and both the mean LCC and mean relative \% of coral cover (RCC) for each species were calculated for each year. All surveys were performed by the same trained divers in order to avoid a bias in the coral identification. The identification of pocilloporid corals at the species level and the validation of the registered species were performed according to the taxonomic criteria described previously [26]. The species LCC was standardized to the transect area and used to estimate the changes in the community structure, as also assessed by the species richness $(\mathrm{S})$, Shannon diversity $\left(\mathrm{H}^{\prime}, \log _{10}\right)$, Pielou evenness $\left(\mathrm{J}^{\prime}\right)$, and Simpson dominance $(\lambda)$ using PRIMER v.6 and PERMANOVA+ [27]. As the data were neither normally distributed nor homoscedastic [28], a one-way univariate permutational ANOVA based on an Euclidean distance matrix and 10,000 permutations was performed following the criteria of [29] with the survey year as a fixed factor. The goal of this analysis was to quantify the community-scale shifts in the benthos over time. 

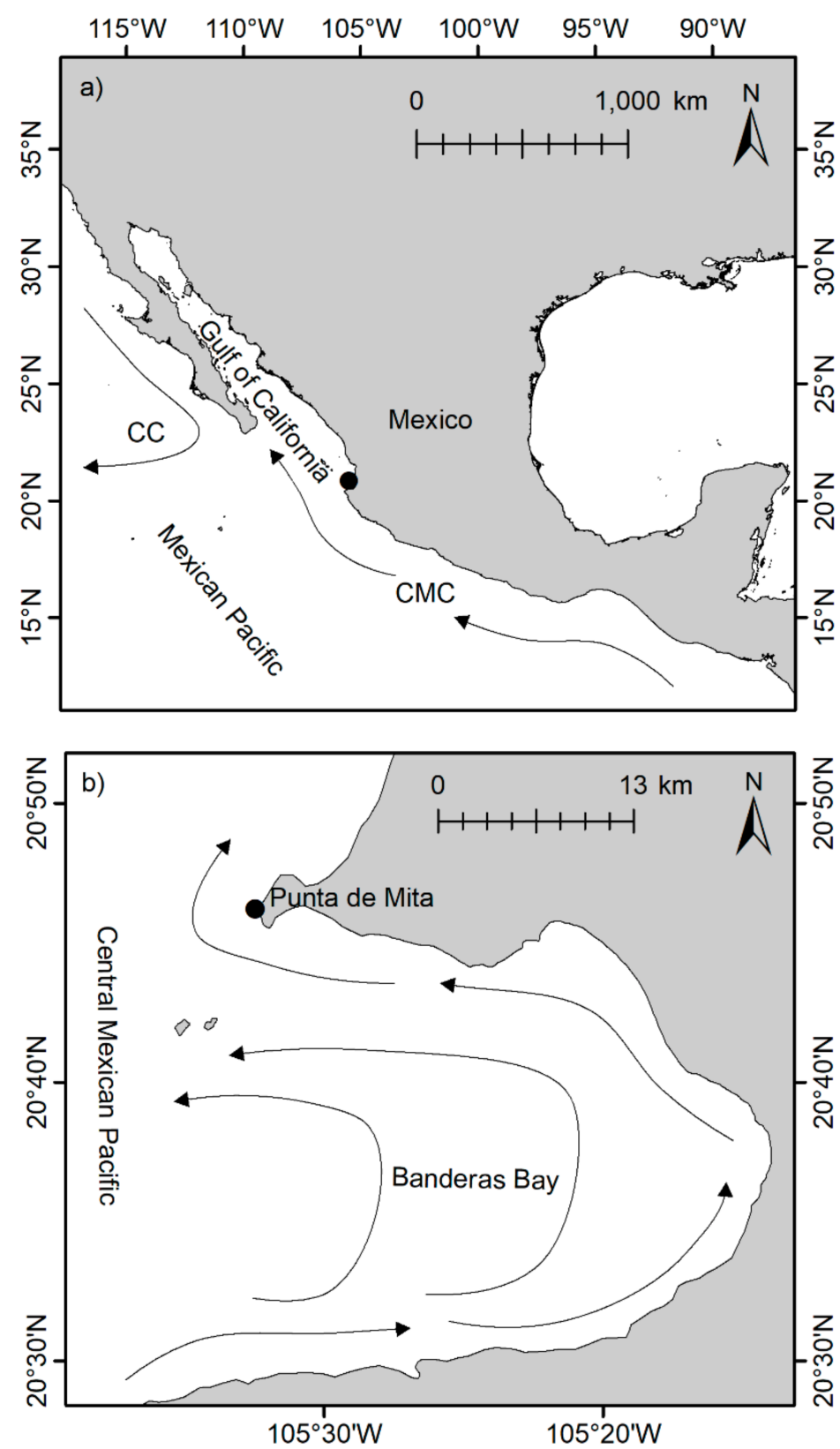

Figure 1. Study area. (a) Central Mexican Pacific (CMP). Arrows depict oceanographic currents. CC $=$ California Current and CMC $=$ Coastal Mexican Current. (b) Study site in the CMP. Arrows show the general geostrophic superficial circulation inside the bay. In both panels, the black dot denotes the study site: Punta de Mita (Nayarit, Mexico).

A PERMANOVA was used to evaluate the LCC of each species vs. time and the data were fourth root-transformed to reduce the influence of the most abundant coral species prior to building a Bray-Curtis similarity matrix (visualized with non-metric multidimensional scaling (nMDS)). The contribution of each coral species was evaluated with a multiple correlation test in PRIMER [27].

Finally, to evaluate the effect of ENSO thermal anomalies on the changes in the coral cover over time, an LCC model using both the historical and current data for the CMP (see Table 1) was constructed with non-linear regressions (Peak, Gaussian, 4 parameter). The model was restricted only to the CMP as the variation in the species composition along the ETP because the differential responses to ENSO events may otherwise have limited our ability to resolve local scale trends. The SST anomaly data were based on the National Oceanic and Atmospheric Administration Oceanic Niño index (ONI) 3.4 (https: / / origin. 
cpc.ncep.noaa.gov/products/analysis_monitoring/ensostuff/ONI_v5.php accessed on 1 February 2021) and the analysis was undertaken with Sigma Plot v.11 [30]. For all statistical analyses, an alpha level of 0.05 was set a priori.

Table 1. Historical live coral cover (LCC) records in the Eastern Tropical Pacific following bleaching and mortality episodes associated with El Niño-Southern Oscillation (ENSO) events. Site abbreviations: GC, Gulf of California; CMP, Central Mexican Pacific; SMP, Southern Mexican Pacific; CR, Costa Rica; PN, Panama; GI, Galapagos Islands; EC, Ecuador; ETP, Eastern Tropical Pacific; NA, data not available.

\begin{tabular}{|c|c|c|c|c|c|c|}
\hline ETP Site & $\begin{array}{c}\text { Years } \\
\text { Surveyed }\end{array}$ & $\underset{*}{\text { ENSO Event }}$ & $\begin{array}{l}\text { Pre-ENSO \% } \\
\text { LCC }\end{array}$ & $\begin{array}{c}\text { Post-ENSO \% LCC } \\
\text { (\% Mortality) }\end{array}$ & $\begin{array}{l}\text { \% LCC After } \\
\text { Recovery }\end{array}$ & Reference \\
\hline Cabo Pulmo (GC) & 1987-1988 & Strong & $\sim 30$ & $(10)$ & NA & [31] \\
\hline GC & 1997-1999 & Very Strong & $\sim 28$ & $25(18)$ & NA & [20] \\
\hline GC & 1996-1998 & Very strong & NA & $59.3(13.6-21.9)$ & NA & [32] \\
\hline GC & 2006 & Weak & NA & No mortality & - & [33] \\
\hline Careyeros (CMP) & 1997-1998 & Very strong & 22 & $1(96)$ & NA & [18] \\
\hline Punta de Mita (CMP) & 1997-1998 & Very strong & 33 & $<5(96)$ & NA & [18] \\
\hline $\mathrm{CMP}$ & 1997-1999 & Very strong & $\sim 15$ & $<5(>60)$ & NA & [20] \\
\hline Punta de Mita (CMP) & 1997-2017 & Very strong & 32.7 & NA & 14.8 & This study \\
\hline Oaxaca (SMP) & 1997-1999 & Very strong & $\sim 57$ & $<5$ & NA & [20] \\
\hline SMP & 2009 & Moderate & $18-65$ & NA & NA & [34] \\
\hline El Chato (SMP) & 2009 & Moderate & 18 & NA & NA & [35] \\
\hline Manzanillo (SMP) & 2009 & Moderate & 59 & NA & NA & [35] \\
\hline Zacatoso (SMP) & 2009 & Moderate & 65 & NA & NA & [35] \\
\hline $\mathrm{CR}$ & $1982-1983$ & Very strong & NA & (50) & NA & [36] \\
\hline Isla del Caño (CR) & 1980-1984 & Very strong & 17.8 & $8.55(46.16)$ & NA & [37] \\
\hline Isla del Caño (CR) & 1985 & Weak & 5.4 & NA & $6.94-18.76$ & [38] \\
\hline Isla del Caño (CR) & 1984-1999 & Several events & $\sim 32$ & $\sim 5(5-52)$ & $\sim 10$ & [39] \\
\hline Cocos Island (CR) & 1978 and 1987 & Very strong & NA & (90) & 2.99 & [40] \\
\hline Cocos Islands (CR) & 1987, 2002 & Several events & 2.99 & NA & 14.87 & [9] \\
\hline Gulf of Papagayo (CR) & 1996-1998 & Very strong & NA & (5.7) & NA & [41] \\
\hline Punta El Bajo (CR) & 1985 & Weak & 45.9 & NA & NA & [42] \\
\hline $\mathrm{PN}$ & 1982-1983 & Very strong & NA & $(75-85)$ & NA & [36] \\
\hline $\mathrm{PN}$ & 1997-1999 & Very strong & NA & (13.1) & NA & [43] \\
\hline Gulf of Chiriqui (PN) & $\begin{array}{c}\text { Pre-1983 and } \\
1984\end{array}$ & Very strong & $60-90$ & $3.3-63.4$ & NA & {$[44]$} \\
\hline Gulf of Chiriquí (PN) & 2016-2018 & Very strong & 50 & $40.8(9.2)$ & NA & [45] \\
\hline Gulf of Panama (PN) & $2016-2018$ & Very strong & 78 & $71.2(6.8)$ & NA & [45] \\
\hline GI & 1982-1983 & Very strong & NA & $(97-100)$ & NA & {$[36,44]$} \\
\hline GI & 1997-1999 & Very strong & NA & $(26.2)$ & NA & {$[43]$} \\
\hline GI & 2007,2012 & Several events & 19.4 & NA & 32.3 & [11] \\
\hline $\begin{array}{l}\text { Shark Bay, Wenman } \\
\text { (GI) }\end{array}$ & 1975,2012 & Several events & 14.4 & NA & 36.94 & [11] \\
\hline $\mathrm{EC}$ & $\begin{array}{l}1975,1986 \\
1998\end{array}$ & Several events & NA & (7) & NA & [40] \\
\hline Overall ETP & 1982-1997 & Several events & 32.7 & 7.1 & 33.9 & [17] \\
\hline
\end{tabular}

* Global ENSO intensity classification according to the ONI index of NOAA.

\section{Results}

Seven species of scleractinian coral and three different morphologies were observed at the study site. Specifically, there were four branching species belonging to the genus Pocillopora Lamarck, 1816: Pocillopora verrucosa (Ellis and Solander, 1786), Pocillopora damicornis (Linnaeus, 1758), Pocillopora capitata (Verrill, 1864), and Pocillopora meandrina (Dana, 1846). There were also two massive species, Porites panamensis (Verrill, 1866) and Pavona gigantea (Verrill, 1869) as well as one sub-massive species (Psammocora stellata; Verrill, 1866). At no sampling time were all seven species found on the reef simultaneously (Figure 2). Branching corals represented $80 \%$ of the relative cover when pooling the data across the years with massive and sub-massive species collectively comprising the remaining 20\%. Prior to the 1997-1998 ENSO event, branching 
corals comprised 96\% upwards of the RCC (Figure 2a). Although branching species remained the most abundant at all sampling times, the cover of massive species has increased in recent years (>12\%, 1997 vs. 2017) and changes in the cover of various species were evident (Figure $2 b$ ). In 1997, the coral cover was dominated by P. damicornis (70\% of the RCC). Since 2015, however, $P$. verrucosa has been the most abundant species with an RCC of $52 \%$ (Figure $2 b$ ).

The PERMANOVA showed no significant changes in the richness, diversity, evenness, or dominance of the coral community species (Table 2). However, the overall LCC decreased 3-fold after the 1997-1998 ENSO event (Tables 2 and 3; Figure 3a). The PERMANOVA revealed temporal differences in the coral assemblage (Pseudo- $F=2.24, P[$ Perm $]=0.0182$; Figure $3 b$ ); this was likely due to the aforementioned observation that $P$. damicornis was the most dominant species prior to the 1997-1998 ENSO event with $P$. verrucosa becoming relatively more common afterwards. These temporal differences were also observed in the overall LCC across the CMP; the model showed a significant relationship between the changes in the historical records of the LCC and thermal anomalies $(R=0.62, p=0.02$; Figure 4$)$, and the coral cover was tightly linked to high-temperature thermal anomalies driven by the ENSO events (i.e., a lower coral cover after strong ENSO events). However, it is important to emphasize that the same pattern was not recorded at Punta de Mita during the 2015-2016 El Niño event (considered to be the most severe over the last 40 years [4]). The LCC was not affected during this period and the PERMANOVA showed no significant differences in the coral cover among 2015, 2016, and 2017 (Figure 3a). Additionally, the model constructed showed that this site exhibited the highest LCC In the CMP during this ENSO period ( 30-35\%; Figure 4$)$.
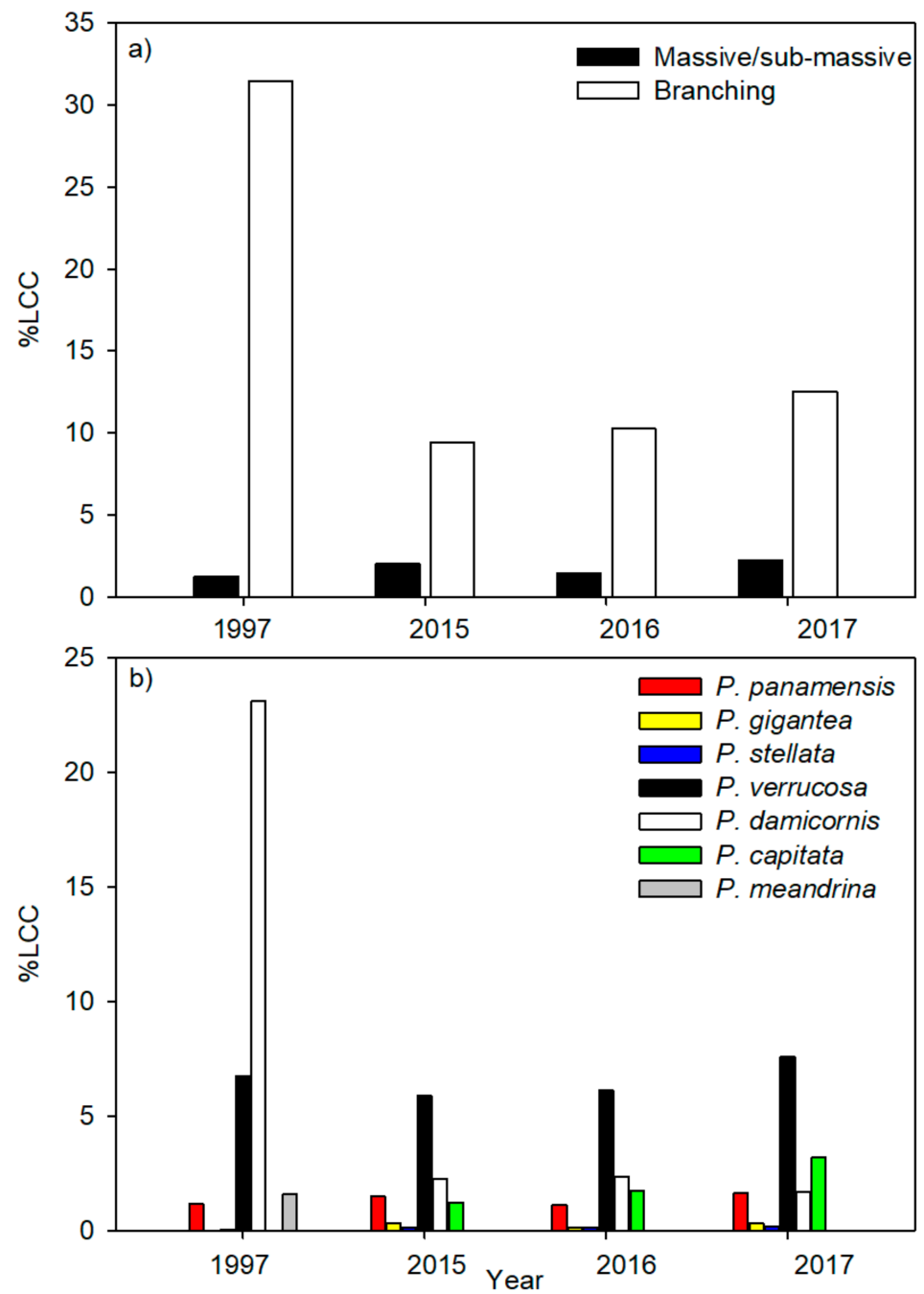

Figure 2. Live coral cover across years by (a) morphology and (b) species. 
Table 2. One-way permutational ANOVA of coral reef (1) species richness, (2) diversity, (3) evenness, (4) dominance (all as indices), and (5) live coral cover (\%).

\begin{tabular}{ccc}
\hline Index & Pseudo-F & $\boldsymbol{P}($ Perm) \\
\hline Number of species & 1.0187 & 0.4242 \\
Diversity $\left(\mathrm{H}^{\prime}\right)$ & 1.9903 & 0.1438 \\
Evenness $\left(\mathrm{J}^{\prime}\right)$ & 2.761 & 0.0666 \\
Dominance $(\lambda)$ & 2.1264 & 0.1238 \\
Live coral cover $(\mathrm{LCC})$ & 6.5954 & $0.0026^{*}$ \\
\hline
\end{tabular}

* Result deemed statistically significant $(p<0.05)$.

Table 3. Post-hoc pairwise $t$-tests for the permutational ANOVA of live coral cover over time.

\begin{tabular}{ccc}
\hline Test & $\boldsymbol{t}$ & $\boldsymbol{P}($ Perm $)$ \\
\hline 1997 vs. 2015 & 4.7504 & $0.004^{*}$ \\
1997 vs. 2016 & 3.4194 & $0.0121^{*}$ \\
1997 vs. 2017 & 2.8015 & $0.037^{*}$ \\
2015 vs. 2016 & 0.077855 & 0.9424 \\
2015 vs. 2017 & 0.92631 & 0.3741 \\
2016 vs. 2017 & 0.64205 & 0.5309 \\
\hline
\end{tabular}

${ }^{*}$ Result deemed statistically significant $(p<0.05)$.
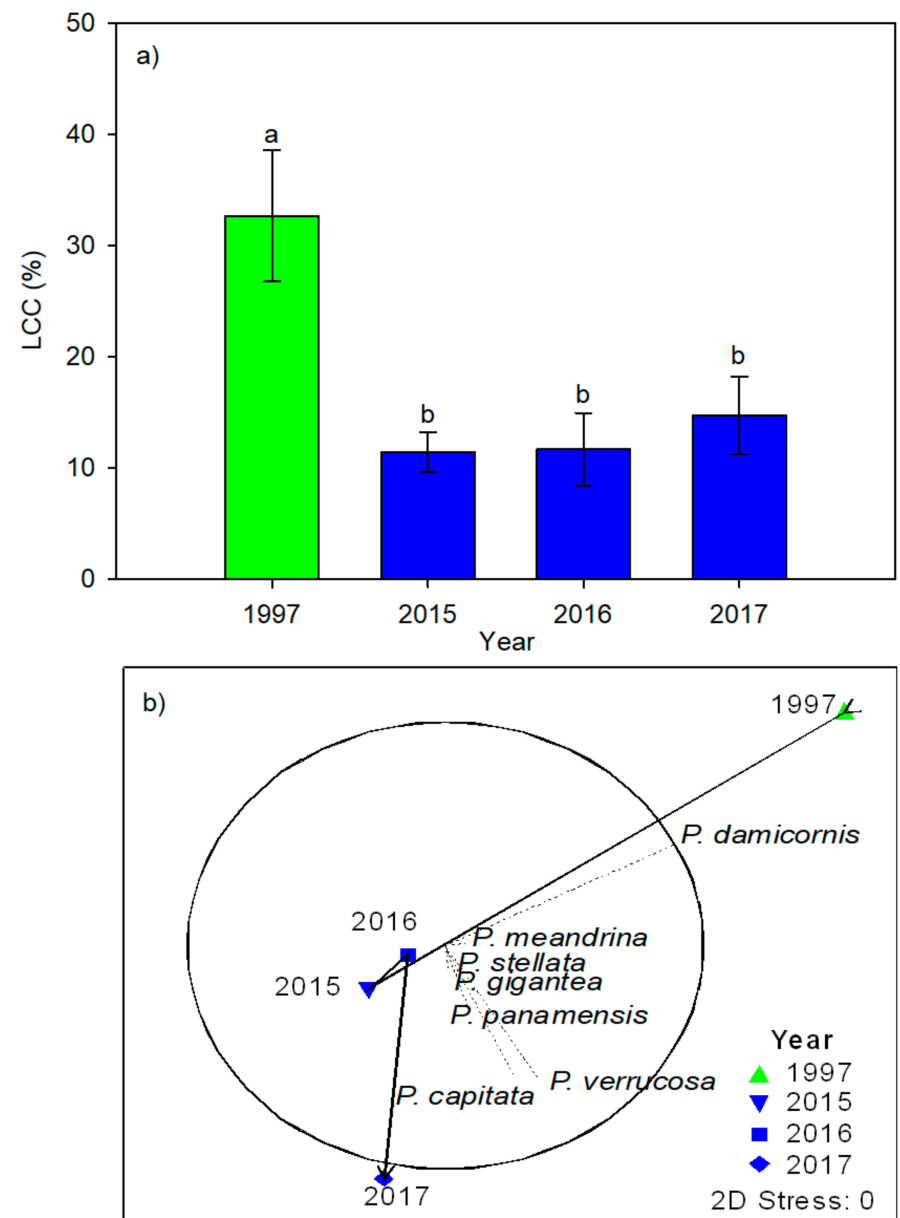

Figure 3. (a) Live coral cover in the study years (mean $\pm \mathrm{SE}$; letters represent groups with significant differences) and (b) variation in coral composition and cover over time as represented by the contribution of the coral species to the existing variation (dotted lines) and the succession trajectory over time (black lines). 


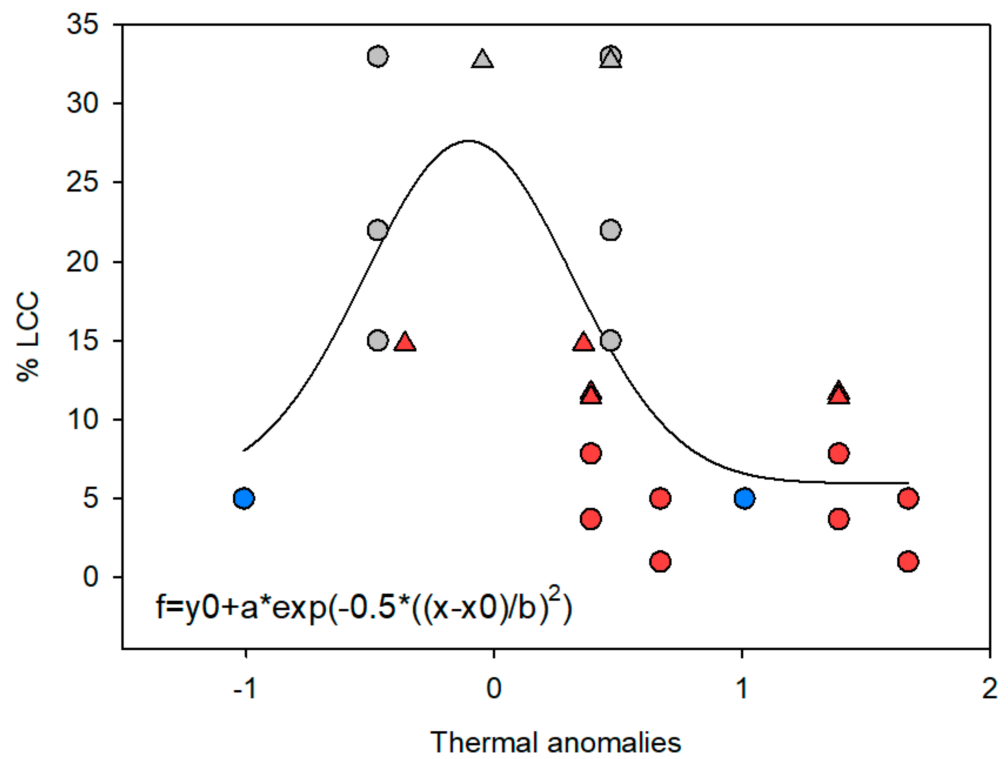

Figure 4. Model describing historical changes in live coral cover (LCC) in the Central Mexican Pacific associated with ENSO thermal anomalies based on the Oceanic El Niño Index of NOAA (x-axis). Gray symbols depict non-ENSO years, red symbols are El Niño years (warm thermal anomalies), and blue dots are La Niña years (cold thermal anomalies). Triangles indicate data from this study.

\section{Discussion}

Coral bleaching and mortality have been observed worldwide over the last three decades $[4,17]$ and the 1997-1998 ENSO resulted in a 96\% decrease in the LCC across the CMP. At Punta de Mita, the LCC was $<5 \%$ after the 1997-1998 ENSO event $[18,20]$. Between 1998 and 2017 (the most recent survey), the LCC rose to $15 \%$ and is on an increasing trend despite the fact that multiple El Niño events have taken place between 1998 and 2015 [4,5], (Figure 3a). Unfortunately, the rate of recovery could not be determined given that surveys were not undertaken between 1998 and 2015; perhaps the increase from $<5 \%$ to $15 \%$ occurred before the survey. Despite this limitation, other studies in the ETP have documented coral recovery or loss over similar periods [10,11] (Table 1) and our results document not only a partial recovery of the coral cover but also the maintenance of coral populations despite more recent ENSO events. Furthermore, they highlight the importance of the continuous monitoring of the sites because although the coral cover may never return to pre-1997 levels, the extant populations appear to now be able to withstand ENSO events and could, therefore, represent important thermal refugia in the region.

The mass mortality event observed following the 1997-1998 El Niño event also caused a change in the structure of the coral community. After the 1997-1998 ENSO event, $P$. damicornis declined whereas $P$. verrucosa increased and is now the most abundant species (Figure $2 \mathrm{~b}$ ). In addition, the dominant massive species observed pre-ENSO were P. panamensis and P. stellata; since then, P. gigantea has settled in the area and gradually become more common. The increase in the cover of the massive and sub-massive species recorded (Figure 2) was not a consequence of the reduction of the proportion of branching Pocillopora colonies; instead, it would appear to stem from enhanced larval recruitment in the area. The massive colonies first recorded during the 2015 survey presented a diameter of $<20 \mathrm{~cm}$ and, considering growth rates of $0.50 \mathrm{~cm} \mathrm{yr}^{-1}$ in the region for $P$. gigantea and $0.33 \mathrm{~cm} \mathrm{yr}^{-1}$ for $P$. panamensis [46], we can assume that the colonies were recruited to the site almost ten years after the 1997-1998 ENSO event. The presence of both species and the evidence of successful sexual reproduction [47] at this site, which was already hypothesized to represent a relatively resilient CMP coral community $[14,48]$, suggests that not only massive but also branching species are being recruited to the reef. A genetic connectivity between the $\mathrm{CMP}$ and other regions such as the Southern Mexican Pacific and the Gulf of California has been observed for both massive [49] and branching species [50]. 
Historical changes in the coral richness and abundance of relative species have also been observed in the western Pacific and Indian Oceans [51,52] but this has not been recorded elsewhere along the eastern Pacific $[10,11]$. Although branching pocilloporids remain the most abundant coral, the dominant species has shifted from $P$. damicornis to $P$. verrucosa and the massive species are increasing in cover over time. As bleaching does not affect all corals equally [13], the changes in the species richness and relative cover seen in this study may be related to the community composition before the 1997-1998 ENSO in which the most abundant species, P. damicornis, also happened to be the least resilient; therefore, it experienced the most severe reduction in abundance with no recovery to date. Indeed, after the 1997-1998 ENSO event, coral recovery in the region was considered to be uncertain or even unlikely [18] given the susceptibility of pocilloporid corals to thermal stress [53]. However, it appears that $P$. verrucosa is characterized by a higher resilience than $P$. damicornis, as has been documented by others [54,55]. This has been linked to their high growth rates [19] and potential to recruit locally [56]. Others have found evidence of branching coral acclimatization to ENSO events [14,20,57]. Considering both the historical mortality records, the increase of the coral cover over the years, and the resistance documented during the last ENSO events at both local and regional levels (see Table 1 and Figures 3 and 4), we hypothesized that the coral community at Punta de Mita should resist future ENSO events.

The coral cover rose slowly from 2015 to 2017, a contrasting trend to other CMP (Figure 4) and ETP coral ecosystems (where the LCC declined up to 50\% following the severe 2015-2016 ENSO event [58]). Even though the LCC has not returned to pre-1997 levels $(\sim 30 \%)$, it has recovered $50 \%$ of this value over a 20 -year period and the coral cover remains higher than that of other competitors such as sponges and macroalgae [15]. The fact that richness, evenness, and diversity have been maintained at pre-1997 levels and that the coral cover has risen from less than 5\% after the 1997-1998 ENSO period [18], pers. observ. to $15 \%$ in 2017 (this study) is a potential statement to the recovery capacity and resilient nature of the scleractinian corals at the study site. These attributes are particularly important given that ENSO events are likely to become stronger and more frequent in the future.

Previous studies in the ETP have documented the changes in the community composition of scleractinian after ENSO events [10,11]. Post-ENSO/bleaching communities tend to shift toward massive species, especially poritids and faviids, which generally experience lower mortality rates during thermal stress events [13,59]. Models from a previous study [60] suggested that branching species in the ETP will gradually disappear and will be replaced by thermo-tolerant massive corals. If this proves to be the case, the CMP may be among the few regions in the ETP where branching pocilloporids persist in a high abundance. However, shifts in coral communities do not always tend toward massive corals [60] and the proliferation of pocilloporids has been observed in other locations (e.g., French Polynesia, see [56]).

Reef recovery depends on many factors, including the physiology of the resident corals and their associated dinoflagellates; the growth rate, reproductive strategy, acclimatization capacity, and type(s) of endosymbionts of a species can all affect the ability of the coral to recover from a disturbance [61]. Massive species in the ETP have low calcification rates (e.g., only $0.49 \mathrm{~g} \mathrm{~cm}^{-2} \mathrm{yr}^{-1}$ for poritids [62]). In contrast, pocilloporids are characterized by relatively high growth rates $\left(5.03 \mathrm{~g} \mathrm{~cm}^{-2} \mathrm{yr}^{-1}\right)$ and many continue to grow relatively rapidly even after El Niño events [19]. Such high post-ENSO growth rates may explain their relative dominance herein as well as the aforementioned capacity for thermo-acclimatization. Larval influx from elsewhere in the CMP is also likely to be important in driving the trends observed although whether the imported larvae have a comparable thermo-tolerance with those released from the potentially stress-hardened colonies of our study remains to be determined. Lastly, pocilloporid corals in other ETP regions are associated with endosymbionts from the genus Durusdinium, a lineage known for its thermo-tolerance [63]; although dinoflagellate genetic analyses were not undertaken 
herein, if the corals of our field site hosted Durusdinium spp. endosymbionts as seen in nearby sites $[14,64]$, this could also have contributed to their ability to withstand the severe 2015-2016 El Niño event.

Coral communities in the Northeastern Tropical Pacific are resilient in that they have survived repeated bleaching events. Although we hypothesized that they would likely withstand future ENSO events, their ability to do so may become compromised by local anthropogenic threats, particularly an accelerated urban growth and tourist development $[1,2,65]$. Specifically, declining water quality due to terrestrial runoff, nutrient enrichment, and sedimentation originating from coastal development $[16,48]$ affect coral reproduction, growth, and survival $[66,67]$. In the study region, urban areas are expected to grow rapidly to meet tourism needs [68]. In the long-term, such stressors may then inhibit the coral recovery [12]. Although the purported resilience to thermal stress arising from ENSO events documented herein is encouraging, it does not necessarily signify that these reefs will persist into the next millennium. At present, they are surviving and strategies to ensure they continue to do so have to be developed.

The Tropical Pacific region was historically characterized as non-optimal for reef development [69] mostly because of the prevailing oceanographic conditions; however, this region as a whole has not suffered in terms of the loss of coral cover as seen in other locales such as the Caribbean and the Indo-Pacific [17]. This dataset is testament to the fact that certain reefs of this region continue to increase in cover of live coral despite a repeated exposure to thermal anomalies caused by ENSO events. Twenty years after the 1997-1998 El Niño event, this resilient reef ecosystem has regained 50\% of the pre-ENSO LCC. Furthermore, diversity has been maintained in recent years; once rare species have increased in abundance and, along with the dominant scleractinians, they continue to persist through repeated (and more frequent) ENSO events.

Author Contributions: All authors contributed to the study conception and design. Field work and data collection was performed by A.P.R.-T., F.A.R.-Z. and V.M.-C. Statistical analyses of field and historical data were performed by V.M.-C. and F.A.R.-Z. The description of the results and initial discussion were developed by V.M.-C., A.B.M., A.L.C.-M. and A.P.R.-T. The first draft of the manuscript was written by V.M.-C. All authors have read and agreed to the published version of the manuscript.

Funding: This research was funded by two National Geographic Society grants, W405-15 and NGS-55349R-19 to APRT, and the project PROCER/CCER/DROPC/09/2016 to ALCM.

Institutional Review Board Statement: Not applicable.

Informed Consent Statement: Not applicable.

Acknowledgments: The authors kindly thank Diana Morales-de-Anda for the assistance in obtaining recent coral cover data, and Adolfo Tortolero Langarica for his assistance when building this study's model. Whilst writing the manuscript, V.M.-C. received a PhD scholarship from the Consejo Nacional de Ciencia y Tecnología (CONACyT; I.D. 332939). The authors also thank the organization PROZONA A.C and the Comisión Nacional de Áreas Naturales Protegidas (CONANP) for their assistance with field operations and two anonymous reviewers for their comments that improved our manuscript.

Conflicts of Interest: The authors declare no conflict of interest.

\section{References}

1. Carpenter, K.E.; Abrar, M.; Abey, G.; Aronson, R.B.; Banks, S.; Bruckner, A.; Chiriboga, A.; Cortés, J.; Delbeek, J.C.; DeVantier, L.; et al. One third of reef-building corals face elevated extinction risk from climate change and local impacts. Science 2008, 321, 560-563. [CrossRef] [PubMed]

2. Burke, L.; Reytar, K.; Spalding, M.; Perry, A. Reefs at Risk Revisited; World Resources Institute: Washington, DC, USA, 2011.

3. Hoegh-Guldberg, O. Coral reef sustainability through adaptation: Glimmer of hope or persistent mirage? Curr. Opin. Environ. Sustain. 2014, 7, 127-133. [CrossRef]

4. Hughes, T.P.; Anderson, K.D.; Connolly, S.R.; Heron, S.F.; Kerry, J.T.; Lough, J.M.; Baird, A.H.; Baum, J.K.; Berumen, M.L.; Bridge, T.C.; et al. Spatial and temporal patterns of mass bleaching of corals in the Anthropocene. Science 2018, 359, 80-83. [CrossRef] 
5. Skirving, W.J.; Heron, S.F.; Marsh, B.L.; Liu, G.; De La Cour, J.L.; Geiger, E.F.; Eakin, C.M. The relentless march of mass coral bleaching: A global perspective of changing heat stress. Coral Reefs 2019, 38, 547-557. [CrossRef]

6. Souter, D.; Planes, S.; Wicquart, J.; Logan, M.; Obura, D.; Staub, F. Status of coral reefs of the world: 2020. In Global Coral Reef Monitoring Network; International Coral Reef Initiative, Australian Institute of Marine Science: Townsville, Australia, 2020.

7. Hoegh-Guldberg, O. Coral reef ecosystems and anthropogenic climate change. Reg. Environ. Chang. 2011, 11, S215-S227. [CrossRef]

8. Brown, B.E. Coral bleaching: Causes and consequences. Coral Reefs 1997, 16, S129-S138. [CrossRef]

9. Hoegh-Guldberg, O.; Mumby, P.J.; Hooten, A.J.; Steneck, R.S.; Greenfield, P.; Gomez, E.; Harvell, C.D.; Sale, P.F.; Edwards, A.J.; Caldeira, K.; et al. Coral reefs under rapid climate change and ocean acidification. Science 2007, 318, 1737-1742. [CrossRef] [PubMed]

10. Guzmán, H.M.; Cortés, J. Reef recovery 20 years after the 1982-1983 El Niño massive mortality. Mar. Biol. 2007, 151, 401-411. [CrossRef]

11. Glynn, P.W.; Riegl, B.; Purkis, S.; Kerr, J.M.; Smith, T.B. Coral reef recovery in the Galapagos Islands: The northernmost islands (Darwin and Wenman). Coral Reefs 2015, 34, 421-436. [CrossRef]

12. Alvarado, J.J.; Beita-Jiménez, A.; Mena, S.; Fernández-García, C.; Cortés, J.; Sánchez-Noguera, C.; Jiménez, C.; Guzmán-Mora, A.G. Cuando la conservación no puede seguir el ritmo del desarrollo: Estado de salud de los ecosistemas coralinos del Pacífico Norte de Costa Rica. Rev. Biol. Trop. 2018, 66, S280-S308. [CrossRef]

13. Baker, A.C.; Glynn, P.W.; Riegl, B. Climate change and coral reef bleaching: An ecological assessment of long-term impacts, recovery trends and future outlook. Estuar. Coast. Shelf Sci. 2008, 80, 435-471. [CrossRef]

14. Rodríguez-Troncoso, A.P.; Carpizo-Ituarte, E.; Cupul-Magaña, A.L. Physiological response to high temperature in the Eastern Tropical Pacific coral Pocillopora verrucosa. Mar. Ecol. 2016, 37, 1168-1175. [CrossRef]

15. Cruz-García, R.; Rodríguez-Troncoso, A.P.; Rodríguez-Zaragoza, F.A.; Mayfield, A.; Cupul-Magaña, A.L. Ephemeral effects of El Niño southern oscillation events on an eastern tropical Pacific coral community. Mar. Freshw. Res. 2020, 71, 1259-1268. [CrossRef]

16. Graham, N.A.J.; Nash, K.L.; Kool, J.T. Coral reef recovery dynamics in a changing world. Coral Reefs 2011, 30, 283-294. [CrossRef]

17. Romero-Torres, M.; Acosta, A.; Palacio-Castro, A.M.; Treml, E.A.; Capata, F.A.; Paz-García, D.A.; Porter, J.W. Coral reef resilience to thermal stress in the Eastern Tropical Pacific. Glob. Chang. Biol. 2020, 26, 3880-3890. [CrossRef] [PubMed]

18. Carriquiry, J.D.; Cupul-Magaña, A.L.; Rodríguez-Zaragoza, F.; Medina-Rosas, P. Coral bleaching and mortality in the Mexican Pacific during the 1997-1998 El Niño and prediction from a remote sensing approach. B Mar. Sci. 2001, 69, $237-249$.

19. Tortolero-Langarica, J.J.A.; Rodríguez-Troncoso, A.P.; Cupul-Magaña, A.L.; Carricart-Ganivet, J.P. Calcification and growth rate recovery of the reef-building Pocillopora species in the northeast tropical Pacific following an ENSO disturbance. PeerJ. 2017, 5, e3191. [CrossRef]

20. Reyes-Bonilla, H.; Carriquiry, J.D.; Leyte-Morales, G.E.; Cupul-Magaña, A.L. Effects of the El Niño-Southern Oscillation and the anti-El Niño event (1997-1999) on coral reefs of the western coast of Mexico. Coral Reefs 2002, 21, 368-372. [CrossRef]

21. Pantoja, D.A.; Marinone, S.G.; Parés-Sierra, A.; Gómez-Valdivia, F. Numerical modeling of seasonal and mesoscale hydrography and circulation in the Mexican Central Pacific. Cienc. Mar. 2012, 38, 363-379. [CrossRef]

22. Portela, E.; Beier, E.; Barton, E.D.; Castro, R.; Godínez, V.; Palacios-Hernández, E.; Fiedler, P.C.; Sánchez-Velasco, L.; Trasviña, A. Water masses and circulation in the Tropical Pacific off Central Mexico and surrounding areas. J. Phys. Oceanogr. 2016, 46, 3069-3081. [CrossRef]

23. Plata, L.; Filonov, A.; Tereshchenko, I.; Nelly, L.; Monzón, C.; Avalos, D.; Vargas, C. Geostrophic currents in the presence of an internal waves field in Bahia de Banderas, Mexico. E-Gnosis 2006, 4, 18.

24. Santiago-Valentín, J.D.; Colley, S.B.; Glynn, P.W.; Cupul-Magaña, A.L.; López-Pérez, R.A.; Rodríguez-Zaragoza, F.A.; BenítezVillalobos, F.; Bautista-Guerrero, E.; Zavala-Casas, D.A.; Rodríguez-Troncoso, A.P. Regional and species sexual reproductive patterns of three zooxanthellate scleractinian corals across the Eastern Tropical Pacific. Mar. Ecol. 2018, e12497. [CrossRef]

25. Plata, L.; Filonov, A. Marea interna en la parte noroeste de la Bahía de Banderas, México. Cienc. Mar. 2007, 33, $197-215$.

26. Veron, J.E.N.; Stafford-Smith, M.G.; Turak, E.; DeVantier, L.M. Corals of the World. 2016 V. 0.01. Available online: http: / / www.coralsoftheworld.org/page/home/?version=0.01 (accessed on 9 March 2021).

27. Clarke, K.R.; Gorley, R.N. Primer6: User Manual/Tutorial; Primer-E: Plymouth, UK, 2006.

28. Zar, J.H. Biostatistical Analysis; Prentice Hall: Hoboken, NJ, USA, 2010.

29. Anderson, M.J.; Gorley, R.N.; Clarke, K.R. PERMANOVA+ for PRIMER: Guide to Software and Statistical Methods; Primer-E Press: Plymouth, UK, 2008.

30. Systat Software, Inc. SigmaPlot, version 11.0; Systat Software, Inc.: Chicago, IL, USA, 2008.

31. Reyes-Bonilla, H. 1987 coral reef bleaching at Cabo Pulmo reef, Gulf of California, Mexico. Bull. Mar. Sci. 1993, $52,832-837$.

32. Iglesias-Prieto, R.; Reyes-Bonilla, H.; Riosmena-Rodríguez, R. Effects of 1997-1998 ENSO on coral reef communities in the Gulf of California, Mexico. Geofis. Int. 2003, 42, 467-471.

33. LaJeunesse, T.C.; Reyes-Bonilla, H.; Warner, M.E. Spring “bleaching” among Pocillopora in the Sea of Cortez, Eastern Pacific. Coral Reefs 2007, 26, 265-270. [CrossRef]

34. López-Pérez, R.A.; Calderón-Aguilera, L.E.; Reyes-Bonilla, H.; Carriquiry, J.D.; Medina-Rosas, P.; Cupul-Magaña, A.L.; HerreroPérezrul, M.D.; Hernández-Ramírez, H.A.; Ahumada-Sempoal, Á.; Luna-Salguero, B.M. Coral communities from Guerrero, Southern Mexican Pacific. Mar. Ecol. 2012, 33, 407-416. [CrossRef] 
35. López-Pérez, R.A.; Guendulain-García, S.; Granja-Fernández, R.; Hernpandez-Urraca, V.; Galván-Rowland, L.; Zepeta-Vilchis, R.; López-López, D. Reef community changes associated with the 2009-2010 El Niño in the Southern Mexican Pacific. Pac. Sci. 2016, 70, 175-190. [CrossRef]

36. Glynn, P.W. Coral reef bleaching in the 1980s and possible connections with global warming. Trends. Ecol. Evol. 1991, 6, 175-179. [CrossRef]

37. Guzmán, H.M.; Cortés, J.; Richmond, R.H.; Glynn, P.W. Efectos del fenómeno de “El Niño Oscilación Sureña” 1982/1983 en los arrecifes de la Isla del Caño, Costa Rica. Rev. Biol. Trop. 1987, 35, 325-332.

38. Guzmán, H.M.; Cortés, J. Coral reef community structure at Caño Island, Pacific Costa Rica. Mar. Ecol. 1989, 10, 23-41. [CrossRef]

39. Guzmán, H.M.; Cortés, J. Changes in reef community structure after fifteen years of natural disturbances in the Eastern Pacific (Costa Rica). Bull. Mar. Sci. 2001, 69, 133-149.

40. Guzmán, H.M.; Cortés, J. Cocos Island (Pacific of Costa Rica) coral reefs after the 1982-1983 El Niño disturbance. Rev. Biol. Trop. 1992, 40, 309-324.

41. Jiménez, C.; Cortés, J.; León, A.; Ruíz, E. Coral bleaching and mortality associated with the 1997-1998 El Niño in an upwelling environment in the Eastern Pacific (Gulf of Papagayo, Costa Rica). Bull. Mar. Sci. 2001, 69, 151-169.

42. Cortés, J. The coral reefs of Golfo Dulce, Costa Rica: Distribution and community structure. Atoll. Res. Bull. 1990, 344, 1-37. [CrossRef]

43. Glynn, P.W.; Maté, J.L.; Baker, A.C.; Calderón, M.O. Coral bleaching and mortality in Panama and Ecuador during the 1997-1998 El Niño-Southern Oscillation event: Spatial/temporal patterns and comparisons with the 1982-1983 event. Bull. Mar. Sci. 2001, 69, 79-109.

44. Glynn, P.W. Coral mortality and disturbances to coral reefs in the Tropical Eastern Pacific. In Global Ecological Consequences of the 1982 1983 El Niño-Southern Oscillation; Glynn, P.W., Ed.; Elsevier: Amsterdam, The Netherlands, 1990; pp. 55-126.

45. Randall, C.J.; Toth, L.T.; Leichter, J.J.; Maté, J.L.; Aronson., R.B. Upwelling buffers climate change impacts on coral reefs of the eastern tropical Pacific. Ecology 2020, 101, e02918. [CrossRef]

46. Tortolero-Langarica, J.J.A.; Carricart-Ganivet, J.P.; Cupul-Magaña, A.L.; Rodríguez-Troncoso, A.P. Historical insights on growth rates of the reef building corals Pavona gigantea and Porites panamensis from the Northeastern tropical Pacific. Mar. Environ. Res. 2017, 132, 23-32. [CrossRef]

47. Santiago-Valentín, J.D.; Rodríguez-Troncoso, A.P.; Bautista-Guerrero, E.; López-Pérez, A.; Cupul-Magaña, A.L. Successful sexual reproduction of the scleractinian coral Porites panamensis: Evidence of planktonic larvae and recruitment. Invertebr. Biol. 2019, 138, 29-39. [CrossRef]

48. Martínez-Castillo, V.; Rodríguez-Troncoso, A.P.; Santiago-Valentín, J.D.; Cupul-Magaña, A.L. The influence of urban pressures on coral physiology on marginal coral reefs of the Mexican Pacific. Coral Reefs 2020, 39, 625-637. [CrossRef]

49. Saavedra-Sotelo, N.C.; Calderon-Aguilera, L.E.; Reyes-Bonilla, H.; López-Pérez, R.A.; Medina Rosas, P.; Rocha-Olivares, A. Limited genetic connectivity of Pavona gigantea in the Mexican Pacific. Coral Reefs 2011, 30, 677-686. [CrossRef]

50. Paz-García, D.A.; Chávez-Romo, H.E.; Correa-Sandoval, F.; Reyes-Bonilla, H.; López-Pérez, R.A.; Medina-Rosas, P.; HernándezCortés, M.P. Genetic connectivity patterns of corals Pocillopora damicornis and Porites panamensis (Anthozoa: Scleractinia) along the west coast of Mexico. Pac. Sci. 2012, 66, 43-61. [CrossRef]

51. Burt, J.; Al-Harthi, S.; Al-Cibahy, A. Long-term impacts of coral bleaching events on the world's warmest Reefs. Mar. Environ. Res. 2011, 72, 225-229.

52. van Woesik, R.; Sakai, K.; Ganase, A.; Loya, A. Revisiting the winners and the losers a decade after coral bleaching. Mar. Ecol. Prog. Ser. 2011, 434, 67-76. [CrossRef]

53. Loya, Y.; Sakai, K.; Yamazato, K.; Nakano, Y.; Sambali, H.; van Woesik, R. Coral bleaching: The winners and the losers. Ecol. Lett. 2001, 4, 122-131. [CrossRef]

54. Paz-García, D.A.; Balart, E.F.; García-de León, F.J. Cold water bleaching of Pocillopora in the Gulf of California. In Proceedings of the 12th International Coral Reef Symposium, Cairns, Australia, 9-13 July 2012.

55. Al-Sofyani, A.A.; Floos, Y.A.M. Effect of temperature on two reef-building corals Pocillopora damicornis and P. verrucosa in the Red Sea. Oceanologia 2013, 55, 917-935. [CrossRef]

56. Tsounis, G.; Edmunds, P.J. The potential for self-seeding by the coral Pocillopora spp. in Moorea, French Polynesia. PeerJ. 2016, 4, e2544. [CrossRef]

57. Rodríguez-Troncoso, A.P.; Carpizo-Ituarte, E.; Pettay, D.T.; Warner, M.E.; Cupul-Magaña, A.L. The effects of abnormal decrease in temperature on the Eastern Pacific reef-building coral Pocillopora verrucosa. Mar. Biol. 2014, 161, 131-139. [CrossRef]

58. Alvarado, J.J.; Sánchez-Noguera, C.; Arias-Godínez, G.; Araya, T.; Fernández-García, C.; Guzmán, A.G. Impact of El Niño 2015-2016 on the coral reefs of the Pacific of Costa Rica: The potential role of marine protection. Rev. Biol. Trop. 2020, 68, S271-S282. [CrossRef]

59. Pratchett, M.S.; McWilliam, M.J.; Riegl, B. Contrasting shifts in coral assemblages with increasing disturbances. Coral Reefs 2020, 39, 783-793. [CrossRef]

60. Cabral-Tena, R.A.; López-Pérez, A.; Reyes-Bonilla, H.; Calderon-Aguilera, L.E.; Norzagaray-López, C.O.; Rodríguez-Zaragoza, F.A.; Cupul-Magaña, A.; Rodríguez-Troncoso, A.P.; Ayala-Bocos, A. Calcification of coral assemblages in the Eastern Pacific: Rrshuffling calcification scenarios under climate change. Ecol. Indic. 2018, 95, 726-734. [CrossRef] 
61. Sweatman, H.; Delean, S.; Syms, C. Assessing loss of coral cover on Australia's Great Barrier Reef over two decades, with implications for longer-term trends. Coral Reefs 2011, 30, 521-531. [CrossRef]

62. Norzagaray-López, C.O.; Calderon-Aguilera, L.E.; Hernández-Ayón, J.M.; Reyes-Bonilla, H.; Carricart-Ganivet, J.P.; Cabral-Tena, R.A.; Balart, E.F. Low calcification rates and calcium carbonate production in Porites panamensis at its northernmost geographic distribution. Mar. Ecol. 2015, 36, 1244-1255. [CrossRef]

63. LaJeunesse, T.C.; Parkinson, J.E.; Gabrielson, P.W.; Jeong, H.J.; Reimer, J.D.; Voolstra, C.R.; Santos, S.R. Systematic revision of Symbiodiniaceae highlights the antiquity and diversity of coral endosymbionts. Curr. Biol. 2018, 28, 2570-2580. [CrossRef]

64. LaJeunesse, T.C.; Smith, R.; Walther, M.; Pinzón, J.; Pettay, D.T.; McGinley, M.; Aschaffenburg, M.; Medina-Rosas, P.; CupulMagaña, A.L.; López-Pérez, A.; et al. Host-symbiont recombination versus natural selection in the response of coral-dinoflagellate symbioses to environmental disturbance. Proc. R. Soc. B 2010, 277, 2925-2934. [CrossRef]

65. Prouty, N.G.; Cohen, A.; Yates, K.K.; Storlazzi, C.D.; Swarzenski, P.W.; White, D. Vulnerability of coral reefs to bioerosion from land-based sources of pollution. J. Geophys. Res. Oceans 2017, 122, 9319-9331. [CrossRef]

66. Fabricius, K.E. Effects of terrestrial runoff on the ecology of corals and coral reefs: Review and synthesis. Mar. Pollut. Bull. 2005, 50, 125-146. [CrossRef]

67. Fabricius, K.E. Factors determining the resilience of coral reefs to eutrophication: A review and conceptual model. In Coral Reefs: An Ecosysztem in Transition; Dubinsky, Z., Stambler, N., Eds.; Springer Science \& Business Media: Berlin/Heidelberg, Germany, 2011; pp. 493-505.

68. Merchand-Rojas, M.A. The inter-state development of Puerto Vallarta and Bahia de Banderas: México. Prob. Des. 2012, 43, 147-173.

69. Glynn, P.W.; Ault, J.S. A biogeographic analysis and review of the far eastern Pacific coral reef region. Coral Reefs 2000, 19, 1-23. [CrossRef] 